Article

\title{
Did the Imperially Commissioned Manchu Rites for Sacrifices to the Spirits and to Heaven Standardize Manchu Shamanism?
}

\author{
Xiaoli Jiang \\ Department of History and Culture, Jilin Normal University, Siping 136000, China; jiangxiaoli33@outlook.com \\ Received: 26 October 2018; Accepted: 4 December 2018; Published: 5 December 2018

\begin{abstract}
The Imperially Commissioned Manchu Rites for Sacrifices to the Spirits and to Heaven (Manzhou jishen jitian dianli), the only canon on shamanism compiled under the auspices of the Qing dynasty, has attracted considerable attention from a number of scholars. One view that is held by a vast majority of these scholars is that the promulgation of the Manchu Rites by the Qing court helped standardize shamanic rituals, which resulted in a decline of wild ritual practiced then and brought about a similarity of domestic rituals. However, an in-depth analysis of the textual context of the Manchu Rites, as well as a close inspection of its various editions reveal that the Qing court had no intention to formalize shamanism and did not enforce the Manchu Rites nationwide. In fact, the decline of the Manchu wild ritual can be traced to the preconquest period, while the domestic ritual had been formed before the Manchu Rites was prepared and were not unified even at the end of the Qing dynasty. With regard to the ritual differences among the various Manchu clans, the Qing rulers took a more benign view and it was unnecessary to standardize them. The incorporation of the Chinese version of the Manchu Rites into Siku quanshu demonstrates the Qing court's struggles to promote its cultural status and legitimize its rule of China.
\end{abstract}

Keywords: The Imperially Commissioned Manchu Rites for Sacrifices to the Spirits and to Heaven; shamanism; Manchu

\section{Introduction}

The Imperially Commissioned Manchu Rites for Sacrifices to the Spirits and to Heaven (Qinding Manzhou jishen jitian dianli) is an important literature on the shamanic rituals observed by the ruling house, which was compiled under the imperial edict of the Qianlong emperor. Its Manchu edition was completed in 1747, and rendered into Chinese thirty-three years later, in 1780. Then the Chinese version was included in the Complete Library of the Four Treasures (Siku quanshu). Traditionally, the shamanic rituals, prayers, and invocations were passed down by word of mouth, with a few being transcribed. This was the first and only codified work of shamanism which had ever been compiled under the imperial auspices.

The Manchu Rites has been in the spotlight for scholars of shamanism, given its significance and influence. For a long time, Chinese scholars believed the Qing court promulgated the Manchu Rites nationwide, standardizing shamanic rituals among common Manchus, which, in turn, resulted in the decline of wild ritual and brought about a similarity of domestic ritual. Wang Honggang argued that after enacting the Manchu Rites, "the Qing court imposed a ban on the shamanic practices and prohibited various Manchu clans from worshiping their own ancestral deities, heroic deities, or animal spirits, commonly known as spirits of wild ritual, in an effort to establish a unified ideology among the subjects of the empire" (Wang 1988, p. 191). Fu Yuguang also thought the Manchu Rites "unified the rules of shamanic rituals performed by the Manchus during the Qing dynasty, fulfilling 
the need for the standardization and reform of native tribal religious rituals that had endured in the northern region for thousands of years, and simplifying the shamanic sacrifices into the worship of ancestors by the clans" (Fu 1990, pp. 9-10). Song Heping and Meng Huiying also held that "the compilation and implementation of the Manchu Rites was a success as the vast majority of the Manchu clans adopted the standardized sacrificial rules, and those rules survived for more than a century" (Song and Meng 1997, p. 95).

These views were long regarded as the final word on the subject and were widely quoted (Du 1990; Fu and Meng 1991; Guo 1992; Shi and Liu 1992; Liu 1992; Zhao 2010). They even made their way into research on the history of the Qing dynasty and of the Manchus. The American scholars also cited these views, believing that the Qing court promulgated the Manchu Rites as a way to construct the ethnic identity of the Manchus and even of the minority groups in the northern region of China (Rawski 2001; Elliott 2009; Di Cosmo 1999).

The reason why some scholars put forth their ideas about this great canon could be that they were trying to understand what attitude the Qing rulers had toward their own culture. Put another way, since the Manchu were a mix of multiple tribes, did the Manchu rulers still worry about the shamanic authority? Did they want to align the cultures of different tribes by standardizing Manchu shamanism in a bid to strengthen their position as rulers? Furthermore, did the rulers try to construct their ethnic identity by standardizing their own culture? It is very important to recognize this issue correctly, which will help us to understand the condition of shamanism in ethnic states.

While Chinese scholars mentioned above were well versed in studying shamanism from the ethnological and religious perspectives, they gave little thought to a thorough research of the Manchu Rites. This essay re-examines and analyzes, in detail, the textual content and various versions of the Manchu Rites and its influence on the ordinary Manchu shamanic rituals so that we can paint an objective picture of the historical realities of those times.

As far as the textual content is concerned, the chief source for the Manchu Rites was the imperial household, and the ceremonies reflected and informed, almost exclusively, court rituals. According to the decree of the Qianlong emperor, the fundamental goals of the compilation were to revise and rectify the rituals in the court rather than to standardize those practiced by the common Manchus.

In terms of the editions of the Manchu Rites, the Manchu version is more practical and significant. There is an important tradition in Manchu shamanism that the shaman must pray to the spirits in the Manchu language. During the Qianlong reign, the Manchu language began to decline, and even the shaman in the court could not pray in the Manchu language flexibly. The Manchu version containing the prayers was a practical manual for the shaman, whereas the Chinese version was useless. After in-depth research, we know that the Manchu version is the unique one issued by the Hall of Military Glory (Wuying dian), which only serves the sacrifice in the court. This demonstrates that the Manchu edition was in limited circulation and the Manchu Rites was never enforced nationwide by the imperial court.

In addition, the influence of the Manchu Rites on the common Manchus was not so great and profound as scholars speculated. The Manchu shamanic sacrifices are generally divided into the domestic sacrifice and the wild sacrifice. The main difference between the two types is that the domestic sacrifice does not need ecstasy performed by the shaman, but the inspirational performance is used in the wild sacrifice. Before the conquest, the wild sacrifice was strictly banned and the restrictions resulted in the declining of wild rituals. In other words, the decline of wild rituals occurred in the preconquest period, instead of being caused by the promulgation of the Manchu Rites. Furthermore, according to the records of genealogies and sacrificial rituals of ordinary Manchu clans, although there are some similarities among the domestic rituals, the differences are also quite obvious, which was not unified even at the end of the Qing dynasty.

After the conquest, compared with the differences between Manchu and Han cultures, the commonalities among the Manchu tribes were more prominent. Shamanism, as the symbolic character of Manchu culture, had a positive significance for the ethnic identity of Manchu, and there is 
no more need to standardize it by enforcing the Manchu Rites. The intention of translating the Manchu Rite into Chinese was to included it in the Siku quanshu, so as to compare Manchu culture favorably with Han culture, and then promote the position of Manchu culture and strengthen the legitimacy of their regime.

\section{Understanding the Purpose of the Manchu Rites Based on Its Textual Content}

The Manchu Rites consists of six volumes, the first four volumes include the Emperor Qianlong's preface, and various sacrifice rituals and corresponding prayers. The fifth and sixth volumes include, respectively, a list and a set of drawings of the sacrificial implements used in the ceremonies. The shamanic sacrifices were mainly held in the Tangse (Tangzi), Kunning Palace (Kunninggong), and the Horse deities' Room (Mashenshi), including the daily ceremonies (Changii), the monthly ceremonies (Yueji), the Great Sacrifice in spring and autumn (Chunqiu Erji Ligan Daji), the seasonal sacrifices (Siji Xianshen), and the ritual of bathing the Buddha (Yufoji), etc. (Yun 1986). Therefore, the textual content is mainly related to the court ceremonies, and the ordinary Manchus could not follow it at this scale.

As the completion of the Manchu Rites drew near, the Qianlong emperor issued a decree, stating the original intention and purpose of the codification of the shamanic sacrifices:

As for the sacrifices of our Aisin Gioro tribe, from the imperial family downwards to the households of imperial princes, we consider all invocations to be important. The shamans of the past were all people born locally, and because they learned to speak Manchu from childhood ... they produced the right words, which fully suited the aim and circumstances of the ritual. Later, since the shamans learned the Manchu words by passing them down from one to another without knowing the language, prayers and invocations uttered from mouth to mouth no longer conformed to the original language and to the original sound. Presently in the families of the princes who left and became separated from the court, the rituals, being transmitted orally from generation to generation, no longer mutually correspond, and various differences have arisen ... Now if, after having revised, corrected and rectified them, we do not act properly by preserving them in writing, and if they continue to be passed down orally for a long time, this cannot but result in their being further neglected and becoming more and more divergent. Therefore, I have appointed to this task princes and ministers, and ordered them to make a respectful and careful examination, to write a work dividing it into sections and chapters, and make drawings of the sacrificial objects to be shown one after the other (Yun 1986, pp. 619-20; Di Cosmo 1999, p. 358).

The imperial decree made definitely the purpose of compiling the Manchu Rites, which was to revise and rectify the sacrificial rituals performed by the shamans of the court and not to standardize those practiced by the common Manchus.

Moreover, the Manchu Rites drew its material solely from the imperial Aisin Gioro clan. In addition to the liturgy used by the shamans of the court, the princes of the five Manchu Banners were ordered to provide their prayers as reference (Yun 1986, pp. 624-25). Starting from Shunzhi's and Kangxi's reigns, the princes were appointed to the Lower Five Banners, they inherited the rituals from the court, which, as a result, resembled the rituals observed by the court. This demonstrates that the content of the Manchu Rites did not touch upon the shamanic rituals of other Manchu clans. Therefore, it would be incorrect to speculate that the sacrificial rituals practiced by the court incorporated the ancestral deity of the Aisin Gioro clan and the natural spirits of other Manchu tribes, as some scholars have done (Guo 1992).

The Manchu Rites also defined the scope of its application, stating that besides the imperial court as well as the princes of the five Manchu Banners, "the members of Uksun (Zongshi) and Gioro (Jueluo) ranked below the princes, as well as the Manchus who worshiped the Gioro deities were permitted to transcribe the Manchu Rites as they pleased" (Yun 1986, p. 625). The Uksun and Gioro 
were two sorts of royal identities ranked according to the blood lineage. The lineal descendants of Nurhaci's father belonged to the Uksun, while the descendants of Nurhaci's uncles belonged to the Gioro (Zhao 1997, p. 3265). However, both the Uksun and Gioro came from the same paternal line, and should observe the same sacrificial traditions. As for "the Manchus who worshiped the Gioro deities", the Manchu Rites made frequent reference to the names of other Gioro clans (Yun 1986, p. 629), which, based on comparisons, are believed to refer to Irgen Gioro, Silin Gioro, and the like. According to the Comprehensive Genealogies of the Eight Banners (Baqi manzhou shizu tongpu), Gioro, a major Manchu clan name, has various branches, such as Irgen Gioro, Susu Gioro, and Silin Gioro (Ortai 1989, p. 181). As a general rule, Gioro is the original clan name, from which Irgen Gioro, Susu Gioro, etc. were derived. In a word, these surnames came from a single clan, which meant that these clans could have observed the same sacrificial traditions and shared the same rituals.

For this reason, the Manchu Rites drew its material from the sacrificial rituals of the imperial Aisin Gioro clan, and the scope of its application can be extended to other Gioro clans such as Irgen Gioro and Silin Gioro, who were permitted to transcribe the Manchu Rites as they pleased rather than being forced to do so. As for other Manchu clans, the Manchu Rites was not aimed to standardize their rituals.

\section{Understanding the Influence of the Manchu Rites Based on the Circulation of Its Various Editions}

The popular view among scholars was that the Manchu Rites, which was an official work commissioned under the order of the Qianlong emperor, would have been made effective nationwide. The Qing dynasty was known for its comprehensive official documentation system, in which all sorts of decrees can be traced. Had the Manchu Rites been enacted nationwide, it would have been a significant move in the efforts of the Qing court to rectify and regulate the traditional Manchu religion, and would have been a grand cultural event. However, there is no evidence to date. Even so, by exploring how far its various editions were distributed, we can infer the reach and influence of the Manchu Rites.

Following the fall of the Qing dynasty, the Korean scholar Kim Kuro was the first to engage in the examination and verification of the Manchu Rites, the results of which formed successive publications of the Manchu-Chinese Manchu Rites for Sacrifices to the Spirits and to Heaven (Manhan Hebi Manzhou Jishen Jitian Dianli) and the Amended Manchu Rites for Sacrifices to the Spirits and to Heaven (Chongding Manzhou Jishen Jitian Dianli). ${ }^{1}$ He prefaced the former with a detailed account of the five editions of the Manchu Rites that he had seen, namely, the Manchu edition by the Hall of Military Glory (Wuying dian); the Chinese edition in Siku quanshu; the Chinese edition by the Grand Secretariat (Neige); the edition in the Comprehensive History of the Eight Banners (Baqi tongzhi) in the reign of the Jiaqing emperor; and the printed edition collected by the Fengtian Manchuria Railway Library, or today's Liaoning Provincial Library (Kim 1934, p. 1). Of the five editions, the last four were all written in Chinese, with just the first written in Manchu. Kim Kuro wrote in his preface to the Amended Manchu Rites: "The original Manchu edition of the Manchu Rites is only the one by the Hall of Military Glory" (Liu 1992, p. 225). Moreover, according to the preface by Jin Yufu to the Amended Manchu Rites, the edition by the Hall of Military Glory that Kim Kuro had seen was, in fact, one of the ancient books from the Shengjing Imperial Palace (Liu 1992, p. 223). The Hall of Pure Tranquility (Qingning gong) in Shengjing, known as Shenyang today, was an important venue for the shamanic practice of the court in the preconquest period. It was not used for performing sacrificial rituals until the Qianlong emperor made a journey

1 The Manchu-Chinese Manchu Rites for Sacrifices to the Spirits and to Heaven that I have seen was completed in 1934 in the lead-type printed version, with its cover bearing the seal with the words "Jilin University Library's Book". The book contained only the first volume with its table of contents marked "to be continued." The Amended Manchu Rites for Sacrifices to the Spirits and to Heaven was completed in 1935, also in the lead-type printed version by Jiangyuan Publishing House (Jiangyuan Jingshe), which should have been based on the former book. The Qingdai Gongting Saman Jisi Yanjiu written by Liu Housheng (Jilin Wenshi Chubanshe, 1992) carried the entire content of the latter book. 
to the east (Dongxun) $)^{2}$ in 1743. The shaman was selected and trained locally (Tuo 1991, p. 6967). In 1754, when the Qianlong emperor set out for the east again, the completed Manchu edition of the Manchu Rites was delivered to Shengjing as training material for the shamans (Tuo 1991, p. 6967). Thus, the delivery of the Manchu edition must have happened at that time only for the purpose of conducting the sacrificial ceremonies at the royal court, which meant that the Manchu Rites was not widely disseminated. This explains why Kim Kuro talked of "the extreme difficulty in accessing the Manchu edition". ${ }^{3}$

Among the four Chinese versions of the Manchu Rites, the Siku quanshu edition is the best-known. The Qianlong emperor stated in his imperial decree that the purpose of translating the Manchu Rites into Chinese was to incorporate it into the Siku quanshu. It is well-known, however, that the complete encyclopedia, which is an enormous collection of Chinese literature, was deposited in seven imperial libraries, including the Wenyuange in the Forbidden City; the Wenyuange in the Old Summer Palace; and the Wenshuoge in Shenging, etc. Thus, the Siku quanshu did not circulate widely in the Qing dynasty at all. The Chinese edition of the Manchu Rites also saw its first five volumes included in the Imperially Commissioned Comprehensive History of the Eight Banners (Qinding baqi tongzhi), which was completed in 1799 , leaving out the sixth volume of "the patterns and drawings of the sacrificial objects" and other sections such as the imperial decree of the Qianlong emperor, and the memorials to the emperor by the minister Agui. The Imperially Commissioned Comprehensive History of the Eight Banners might have had a better chance of gaining wide circulation, as a careful study of the Suiyuan qizhi-the records of the garrison duties of the eight banners in various locations of Suiyuan-shows that its appendix carries the names of the books issued in the reigns of all the emperors in the Qing dynasty. Among those names, only the "Chinese Edition of Comprehensive History of Eight Banners with 20 cases and 500 tomes" (Ma 1994, p. 357) has been found and this is considered the First Collection of the Comprehensive History of the Eight Banners (Baqi tongzhi chuji) based on its name and the number of copies. ${ }^{4}$ This book was compiled in 1739, when the Manchu Rites had not come into being. Another book, Shengjing Decrees and Regulations for Reference (Shengjing dianzhi beikao), also carries a detailed list of the books in the Qing dynasty. Unfortunately, the Imperially Commissioned Comprehensive History of the Eight Banners is not on this list, ${ }^{5}$ which, in turn, suggests that this book was in limited circulation as well. Furthermore, the book contains 342 volumes and was distributed to the garrison administrative offices at the provincial level at most, making it difficult for ordinary bannermen to have accessed it. Even assuming that Qianlong intended to popularize the Manchu Rites using this approach, why did he not include the Manchu version of the Manchu Rites, for the shamans paid the most heed to the prayers at the sacrificial rituals and they must have chanted the prayers in the Manchu language? In contrast, the Chinese version of the prayers are useless for the shamans to perform their rituals and sacrifices. In addition to the above editions of the Manchu Rites, Kim Kuro also mentioned the Chinese edition by the Grand Secretariat and the printed edition at the Fengtian Manchuria Railway Library, both of which are lost. These two editions were all in Chinese so that they could not have served the purpose of communicating the Manchu Rites to the common Manchus.

Suo Ning'an, who was born into the Niohuru clan and made compiler at the National History Academy (Guoshiguan Bianxiu) in Qianlong's period, wrote the Collection of Four Manchu Rituals (Manzhou sili ji), which was completed in 1796. One of the chapters of the book is titled, Etiquette of Rituals and Sacrifices of Manchus (Manzhou jishen jitian yizhu), which paints a picture of how his clan

2 In the Qing dynasty, the emperors often returned to their hometown in Northeast China to visit their ancestors' mausoleums, known as the Dongxun.

3 Kim Kuro. Man Han Hebi Manzhou Jishen Jitian Dianli (Collection of Jilin University Library, Unique Copy), p. 1.

4 First Collection of Comprehensive History of the Eight Banners (Baqi tongzhi chuji) registers 250 volumes that can be bound in 500 tomes, whereas the Imperially Commissioned Comprehensive History of the Eight Banners (Qinding baqi tongzhi) consists of 342 volumes.

5 See Shengjing Dianzhi Beikao, In Zhongguo Shaoshu Minzu Guji Jicheng (Hanwenban) (Sichuan Minzu Chubanshe 2002), pp. 579-80. 
practiced rituals. Going by his preface, it was only in his capacity as compiler at the National History Academy that Suo was able to see the Manchu edition of the Manchu Rites (Suo 1988, p. 596), let alone the common Manchus. Moreover, it should be noted that, for the compilation of rituals observed by his own clan, Suo did not follow the Manchu Rites but referred to old manuscripts and consulted elderly members of his clan (Suo 1988, p. 599). Had the court enforced the Manchu Rites, Suo would not have made these remarks about his experience.

Ever since the 1980s, Chinese scholars studying shamanism have made extensive investigations into the Manchu clans of Northeast China, collecting a mass of the folk manuscripts on shamanic rituals, but have never found any transcription of the Manchu Rites. This demonstrates that the Manchu Rites had limited circulation and was never enforced nationwide by the imperial court.

\section{The Decline of Wild Ritual Cannot Be Attributed to the Manchu Rites}

The Manchu shamanic rituals were generally classified as domestic ritual and wild ritual (Fu and Meng 1991, p. 66). The domestic ritual centered on liturgically-based sacrifices made to heaven and to the ancestor spirits. The shamans lead the domestic ritual were more like priests who only perform the rituals and chant the prayers. The wild ritual, with its sacrifices to various animal spirits and human heroic spirits, appears closer to the original shamanic ritual, in which shamans directly engage spirits through possession, and even require the help of special assistants, whereas in the Qing dynasty, the domestic ritual was the most widespread type of shamanic observance among Manchu clans, and the wild ritual was rather rare. A number of scholars have ascribed the decline in wild ritual to the promulgation of the Manchu Rites and the standardization of the shamanic sacrifices. They believed that the ordinary Manchus were forced to align themselves with the court and abandon wild ritual. However, the real reason was that it was the result of the reformation that had been initiated in the preconquest period and not because of the Manchu Rites in the reign of Qianlong (Chen 1993; Jiang 2008).

Before the conquest, the shamanic sorcery prevailed in the community. The Korean envoy Lee Minhuan was captured and imprisoned in Hetu Ala city, where he saw that "diseases that could not be healed with medicine or acupuncture would be treated by sorcerers or sorceresses who sacrificed pigs and burned joss paper to pray for recovery. The pigs and paper, which were used to bring dying people to life, were so expensive in that community" (Lee 1978, p. 44). Not only were the sacrificial offerings lavish and extravagant, but the sorcery was also rampant. On one occasion, Cuyen, the eldest son of Nurhaci, even resorted to sorcery spells to usurp the crown. "When his father left on a military campaign against the Ula tribe, he did not worry about whether his father could defeat the enemy but attempted to use sorcery to curse his father, his brothers and, five ministers, and incinerated the paper of sorcery spells to Heaven". ${ }^{6}$ Cuyen was sentenced to death after his conspiracy was brought to light.

To combat the practice of sorcery, the imperial court imposed many restrictions in Hongtaiji reign (1627-1643). An imperial decree issued in 1632, stated: "Any sorcerers, sorceresses, or other astrologers who claim to have the ability to practice divination, or dare to seduce women, or swindle money, shall be put to death. Furthermore, the Niru, Bosoku, and the masters of the sorcerers and sorceresses, as well as those who invited the sorcerers and sorceresses shall be punished accordingly." (Yun 1991, p. 10,551). In 1636, the chief censor was ordered "to report the cases where some claimed to be shamans and performed demonic magic by writing incantation on paper strips and casting spells to bully and defraud others". ${ }^{7}$ It was also stipulated that "the Taoist priests from the Manchurian, Mongolian, and Han people shall not perform magic to ward off evil, forecast weal and woe, or stir up the public.

\footnotetext{
Re-translation of The Old Manchu Archives (Chongyi manwen laodang) (Liaoning Daxue Lishixi Yinben, 1978), v. 1, p. 20. The First Historical Archives of China, and History Research Institute under Chinese Academy of Social Sciences, Old Manchu Archives (Manwen laodang) (Zhonghua Shuju, 1990), p. 1512.
} 
Any disobedience shall be followed by a capital crime and the family of the one that invited the priests to do so shall be liable for compensating for the master of the priests". ${ }^{8}$

The imposition of such bans dealt a severe blow to shamanic practices. According to the Original Archives of the Ministry of Punishments in Shengjing (Shengjing xingbu yuandang), seven of the judicial cases settled between 1638 and 1639 were about sorcery; two of them resulted in the death penalty while the other five attracted whipping, impalement of ears and nose, and confiscation of properties. This shows that the bans were not taken lightly.

The realities above can be regarded as a reformation of Manchu shamanism in the preconquest period. The clampdown on the shamanic practice of witchcraft, especially the execution of those shamans who claimed to have access to spirits, inevitably led to the discontinuation of wild ritual and their eventual decline. Thus, the decline of wild ritual had begun even before the conquest which was not the result of the promulgation of the Manchu Rites.

\section{Domestic Ritual among the Manchu Commoners Was not in Full Accord with the Manchu Rites}

As the decline of wild ritual, the domestic ritual became the main observance. In fact, the shamanic rituals of the court also belonged to the domestic ritual type, which could be performed by the shamans without the skills of possession. And there were quite a few similarities between the rituals of the court and the common Manchus, with both involving the "light-extinguishing" sacrifice (Beideng ji) held at midnight,${ }^{9}$ the sacrifice for blessing kids by putting a blessed cloth strip on kids' clothes (Huansuo), and the sacrifice to Heaven by lifting the spirit-pole (Ligan jitian), among others. This led many scholars to believe that these similarities were a result of the standardization brought about by the Manchu Rites.

However, the domestic ritual was a rather old shamanic ritual, some records show that it was in place long before the compilation of the Manchu Rites. The Sacrifices Book of the Manchu Silin Gioro Clan (Manzhou xilin jueluo shi jisi shu), compiled by Ortai, a prominent minister in the reign of the Yongzheng and Qianlong emperors, makes mention of the "light-extinguishing" sacrifice held at midnight and the thanksgiving to Heaven by lifting the spirit-pole, which were handed down from his mother. Going by the lifespan of Ortai, one can argue that the completion of the Sacrifice Book of the Manchu Silin Gioro Clan precedes that of the Manchu version of the Manchu Rites (Ortai 2003) ${ }^{10}$ This demonstrates that the details of domestic ritual were already well established and were not a consequence of the standardization enforced by the Qing court. Moreover, the Manchu clans originated from different tribes but lived in close proximity and shared the same cultural origins, making it likely that they established a set of similar sacrificial rules through a long period of communication.

With regard to the details of domestic ritual, there were considerable differences between what the commoners observed and what the royal court observed as well. In 1771, the shaman Chang Qing from the Susu Gioro clan compiled the Complete Book of Sacrificial Chants for Sorcerers and Sorceresses (Jisi quanshu wuren songnian quanlu), which recorded a unique shamanic ritual that was characterized by the sheep sacrifice ${ }^{11}$, "the worship of Mongolian ancestors in the yard," and the putting together of an altar using sorghum straws, willow twigs, and blue fabric (Huang and Se 2002, pp. 118-27). ${ }^{12}$ These rituals were far different from that of the court. Furthermore, the Silin Gioro and Susu Gioro clans were considered "the Manchus who worshipped the Gioro Gods" mentioned in the Manchu Rites and, thus, earned entitlement to its transcription. However, they did not observe the imperial rituals,

8 The Scripture of Veritable Records of Qing TaiZong (Taizong shilu gaoben) (Liaoning Daxue Lishixi Yinben, 1978), pp. 13-14.

9 The "light-extinguishing" sacrifice (Beideng ji) was held at midnight, the light would go out when the shaman prayed to the deities.

10 Ortai was born in 1677, and died in 1745, while the Manchu edition of the Manchu Rites was completed in 1747.

11 The shamanic ritual of the court sacrificed pigs.

12 The court never set the alter in the yard. 
and recorded their own sacrificial traditions. All of this illustrates that, even for clans such as the Silin Gioro and Susu Gioro, their domestic ritual had not been standardized by the Manchu Rites.

The Manchu bannermen that garrisoned Northeast China had been performing domestic ritual until the end of the Qing dynasty, but as far as we have seen, in the 11 genealogical records, ${ }^{13}$ the rituals varied considerably among different Manchu clans. Regarding the sacrificial ceremony, the Gaizhou Guwalgiya clan had no the "light-extinguishing" sacrifice (Beideng ji) and the sacrifice for blessing kids (Huansuo). ${ }^{14}$ The Fengcheng Guwalgiya clan put a pillow as the alter in the "light-extinguishing" sacrifice (Fu and Zhang 1996, p. 201). The Guwalgiya clan of the Plain White Banner placed a pillow with a folded red cotton coat and a mirror as the alter in the "light-extinguishing" sacrifice. ${ }^{15}$

The New Manchus ${ }^{16}$ also believed in shamanism and celebrated it in a unique way. According to the Genealogy of the Kuyala Clan in Heilongiiang (Heilongjiang kuyala shi jiapu), the clan performed sacrifices to the "Horse Ancestor" (Mazu shen) and set up an altar using a pillow and men's robes. In their worship of stars, they prepared a piece of white coarse paper and folded it up diagonally before hanging the paper on a willow twig. They also threaded seven chicken wing feathers onto a hemp rope, then placed the rope on the willow twig for the purpose of offering (Ming 2003, pp. 587-90).

The Manchu bannermen that were garrisoned in various provinces also continued the shamanic rituals, either according to their own traditions or in a dramatically different manner. Of those who were garrisoned in Qingzhou, "some clans worshipped the Big Dipper. They made seven stacks of buckwheat pies for the sacrificial rituals, with each stack containing seven pies, and the stacks were placed in the shape of the Big Dipper. Every stack had a cup of liquor placed in front. Seven pairs of chopsticks made of sorghum straws were prepared, with each pair inserted into the top of one pie stack, to show veneration to the Big Dipper. The families with the surname Sumuru also worshiped the Hudou Stars" (Li et al. 1999, p. 128). By comparison, among the Manchu bannermen located in Guangzhou, each banner set up the clan hall (Citang) to remember their ancestors, and launched sacrificial activities at the Qingming Festival or the Tomb Sweeping Day by setting off firecrackers and inviting monks to chant and stage shows such as the "cymbal dance" (Wang 1990, pp. 162-63).

From noble families to commoners, from the Northeastern homeland to the provincial garrisons, and from the old Manchuria to the new one, all the Manchus kept their unique ways of performing the sacrificial ceremonies, and often these were not in sync with those of the imperial rituals.

\section{Conclusions}

Although it is possible that the Manchu Rites may have had some impact on the Manchu commoners, the court had not in fact leveraged the work for administrative power to popularize and standardize Manchu shamanism.

There could have been some secessionist forces hidden among different Manchu tribes that the ruling Aisin Gioro clan needed to fight before their conquest of China. However, after taking control of China, the Manchus became the ruling ethnic group, which established a common identity for those tribes and formed the ethnic boundary obviously. The Manchu tribes had common interests and a shared history memory of their ancestor's dedication to fights which held them together tightly. At this point, the slight cultural differences among them would not have undermined the ruling of the Manchu state. Meanwhile, the negative features of shamanism had been brought under control in the preconquest period, and later became a common cultural element among the different Manchu tribes and helped to bolster their ethnic identity naturally. Therefore, it was unnecessary to conduct a

13 Of the 11 genealogical records, five are of the Guwalgiya clan and the rest six of the Nara clan, the Socolo clan, the Husihari clan, the Fuca clan, the Wanggiya clan, and the Tongiya clan, respectively.

14 See the Genealogy of the Guwalgiya Clan (Guaeriia shi zongpushu). collected by the Guan clan in Gaizhou city, Liaoning province.

15 See the Genealogy of the Manchu Guan Clan of Plain White Banner (Zhengbaiqi manzhou guanshi jiapu), collected in Eight Banner Genealogy Library of Jilin Normal University.

16 New Manchus (Ma. Ice Manchu) refer to the tribes which were placed into the Eight Banners after the conquest. Those who joined the Eight Banner before the conquest were called Old Manchus (Ma. Fe Manchu). 
rectification and formalization of shamanic rituals. The Qianlong emperor stated in his preface to the Manchu Rites that "sacrificial rituals among the Manchu clans varied but could be observed according to the local traditions" (Yun 1986, p. 620), suggesting that the rulers took a more benign view of the cultural diversity of the Manchu tribes.

In Chinese history, ethnic minorities that established the dynasties to reign over the central region of China were always haunted by anxiety about their legitimacy as rulers. Being unable to anchor that legitimacy in the blood lineage, they sought to do so by gaining a foothold in the cultural domain. The Manchu Rites was compiled in Manchu first and had nothing to do with Han culture in content or form. Thirty-three years later, it was translated into Chinese, only so that it could be included in the Siku quanshu. Given the fact that this encyclopedia is a brilliant collection of Chinese cultural works, the Qing rulers' intention of including in the Siku quanshu the Chinese edition of the Manchu Rites that bore the signature Manchu culture, is to compare Manchu culture favorably with Han culture. Furthermore, the Chinese edition of the prayers and invocations featured ornate and mysterious lines that were the hallmarks of the style of ancient Chinese rhythmical prose. In the final analysis, the rulers did so for no other reasons than to bring Manchu shamanism on a par with ancient Han Chinese rites and elevate the position of Manchu culture, thereby strengthening the legitimacy of their regime.

Funding: This research received no external funding.

Conflicts of Interest: The author declares no conflict of interest.

\section{References}

Chen, Jiexian. 1993. Qingtaizong shidai de Samanjiao 清太宗时代的萨满教. In Qingzhu Wangzhonghan Xiansheng Bashi Shouchen Lunwenji 庆祝王锤翰先生八十寿辰论文集. Shenyang: Liaoning Daxue Chubanshe.

Di Cosmo, Nicola. 1999. Manchu Shamanic ceremonies at the Qing court. In State and Court Ritual in China. Edited by Joseph P. McDermott. Cambridge: Cambridge University Press, pp. 352-98.

Du, Jiaji. 1990. Cong Qingdai de Gongzhong Jisi he Tangzi Jisi Kan Samanjiao 从清代的宫中祭祀和堂子祭祀看萨 满教. Manzu Yanjiu 满族研究 1: 45-49.

Elliott, Mark. 2009. Emperor Qianlong: Son of Heaven, Man of the World. Upper Saddle River: Pearson Education Inc. $\mathrm{Fu}$, Yuguang. 1990. Samanjiao yu Shenhua 萨满教与神话. Shenyang: Liaoning Daxue Chubanshe.

Fu, Yuguang, and Huiying Meng. 1991. Manzu Samanjiao Yanjiu 满族萨满教研究. Beijing: Beijing Daxue Chubanshe. Fu, Bo, and Deyu Zhang. 1996. Manzu Jiapu Yanjiu 满族家谱研究. Shenyang: Liaoning Guji Chubanshe.

Guo, Shuyun. 1992. Manzhou Jishen Jitian Dianli Lunxi 《满洲祭神祭天典礼》论析. Shehui Kexue Jikan 社会科学辑刊 5: 80-85.

Huang, Qiang, and Yin Se. 2002. Samanjiao Tushuo 萨满教图说. Beijing: Minzu Chubanshe.

Jiang, Xiaoli. 2008. Qing Ruguan qian Samanjiao Biange Lunxi 清入关前萨满教变革论析. Heilongjiang Minzu Congkan 黑龙江民族丛刊 2: 107-11.

Kim, Kuro. 1934. Man Han Hebi Manzhou Jishen Jitian Dianli 满汉合璧满洲祭神祭天典礼. Available online: http:/ /ishare.iask.sina.com.cn/f/15517845.html (accessed on 4 December 2018).

Lee, Minhuan. 1978. Jianzhou Wenjianlu 建州闻见录. Shenyang: Liaoning Daxue Lishixi Yinben.

Li, Fengqi, Yumin Tang, and Kui Li. 1999. Qingzhou Qicheng 青州旗城. Jinan: Shandong Wenyi Chubanshe.

Liu, Housheng. 1992. Qingdai Gongting Saman Jisi Yanjiu 清代宫廷萨满祭祀研究. Changchun: Jilin Wenshi Chubanshe. Ma, Xiedi. 1994. Hangzhou Suiyuan Jingkou Fuzhou Baqi Zhi. Shenyang: Liaoning Daxue Chubanshe.

Ming, Hai. 2003. Heilongjiang Kuyala Shi Jiapu 黑龙江库雅喇氏家谱. In Beijing Tushuguan Cang Jiapu Congkan-Minzu Juan 北京图书馆藏家谱丛刊（民族卷）. Beijing: Beijing Tushuguan Chubanshe, vol. 46.

Ortai, Xilin Gioro. 1989. Baqi Manzhou Shizu Tongpu 八旗满洲氏族通谱. Shenyang: Liaoshen Shushe, vol. 12.

Ortai, Xilin Gioro. 2003. Manzhou Xilin Jueluo Shi Jisishu 满洲西林觉罗氏祭祀书. In Beijing Tushuguan Cang Jiapu Congkan—Minzu Juan 北京图书馆藏家谱丛刊（民族卷）. Beijing: Beijing Tushuguan Chubanshe, vol. 44.

Rawski, Evelyn. 2001. The Last Emperors: A Social History of Qing Imperial Institutions. Oakland: University of California Press.

Shi, Guangwei, and Housheng Liu. 1992. Manzu Saman Tiaoshen Yanjiu 满族萨满跳神研究. Changchun: Jilin Wenshi Chubanshe. 
Song, Heping, and Huiying Meng. 1997. Manzu Saman Wenben Yanjiu 满族萨满文本研究. Taibei: WuNan Tushu Chuban Youxian Gongsi.

Suo, Ning'an. 1988. Manzhou Sili Ji 满洲四礼集. In Beijing Tushuguan Guji Zhenben Congkan 北京图书馆古籍珍本丛刊. Beijing: Shumu Wenxian Chubanshe, vol. 99.

Tuo, Jin. 1991. Qinding Daqing Huidian Shili (Jiaqing Chao) 钦定大清会典事例（嘉庆朝）. In Jindai Zhongguo Shiliao Congkan Sanbian 近代中国史料丛刊三编第六十七辑. Taibei: Wenhai Chubanshe, vol. 895.

Wang, Honggang. 1988. Manzu Samanjiao de Sanzhong Xingtai jiqi Yanbian 满族萨满教的三种形态及其演变. Shehui Kexue Zhanxian 社会科学战线 1: 187-93.

Wang, Zongyou. 1990. Guangzhou Manzu Jianshi 广州满族简史. Guangzhou: Guangdong Renmin Chubanshe.

Yun, Lu. 1986. Qinding Manzhou Jishen Jitian Dianli 钦定满洲祭神祭天典礼. In Wenyuange Siku quanshu 文渊阁四库全书. Taibei: Shangwu yinshu Chubanshe, vol. 657.

Yun, Lu. 1991. Daqing Huidian (Yongzheng Chao) 大清会典（雍正朝）. In Jindai Zhongguo Shiliao Congkan Sanbian 近代中国史料丛刊三编第七十八辑. Taibei: Wenhai Chubanshe, vol. 163.

Zhao, Er'xun. 1997. Qingshi Gao 清史稿. Beijing: Zhonghua Shuju, vol. 114.

Zhao, Zhizong. 2010. Manzu Saman Shenge Yanjiu. Beijing: Minzu Chubanshe.

(C) 2018 by the author. Licensee MDPI, Basel, Switzerland. This article is an open access article distributed under the terms and conditions of the Creative Commons Attribution (CC BY) license (http:/ / creativecommons.org/licenses/by/4.0/). 